\title{
SYNTHESIS, CHARACTERIZATION, THEORETICAL AND BIOLOGICAL STUDIES OF A NEW MACROCYCLE SCHIFF BASE WHITH Co(II), Ni(II), Cu(II) AND Zn(II) COMPLEXES
}

\author{
ESMAIEL SOLEIMANI, SAYED ALI NAGHI TAHERI*, MOHSEN SARGOLZAEI
}

Faculty of Chemistry, Shahrood University of Technology, Shahrood, Iran

\section{ABSTRACT}

A new macrocycle Schiff base, by the reaction between benzene-1,2-diamine and 3-bromo-pentane-2,4-dione, is introduced and a series of its complexes with $\mathrm{Co}(\mathrm{II}), \mathrm{Ni}(\mathrm{II}), \mathrm{Cu}$ (II) and $\mathrm{Zn}$ (II) have been synthesized. FTIR, ${ }^{1} \mathrm{H}$ and ${ }^{13} \mathrm{C}$ NMR, and TGA, also biological activities of all complexes and the electronic spectral data have been investigated. The results show that there are no water molecules, also that macrocycle Schiff base is bonded to the metal ions through nitrogen atoms of four azomethine groups via an octahedral arrangement containing N4 tetra-dentate donor sites on planar and two Cl atoms occupying the other two opposed sites. The corresponding $\mathrm{Cu}(\mathrm{II})$ and $\mathrm{Zn}(\mathrm{II})$ complexes showed good antibacterial and antifungal activities. The molecular geometry, frontier molecular orbitals and Mulliken atomic charge of the compounds are investigated theoretically using DFT method.

Keywords: Macrocycle Schiff base, DFT calculations, thermal analysis, molecular modeling, antibacterial activity.

\section{INTRODUCTION}

Schiff bases offer a versatile and flexible categories of ligands capable of binding to transition, non-transition, lanthanide, and actinide metal ions to give corresponding complexes with suitable properties for theoretical studies and/ or practical applications. ${ }^{1-4} \mathrm{~A}$ large number of Schiff bases and their complexes have been studied because of their interesting and important properties such as their ability to reversibly bind to oxygen, ${ }^{5}$ being anti-bactericide, and fungicide agents, ${ }^{6,7}$ and also their application in oxidation reactions of organic compounds. ${ }^{8,9}$

These multiple roles played by the naturally occurring macrocycle in biological systems is well known. The chemistry of synthetic macrocycle compounds is also of great importance due to their use as pigments and dyes, MRI contrast agents and models for naturally occurring macrocycles..$^{10,11}$ Many macrocycle compounds have been reported showing antibacterial and antifungal activities. ${ }^{12,13}$

The synthesis of some new Schiff bases bearing a 1,3,4-thiadiazole moiety by reaction of 2-amino-5-mercapto-1,3,4-thiadiazole with aromatic aldehydes under acidic and phase transfer catalyst (PTC) conditions was studied. The antibacterial activity of these compounds was investigated against Staphylococcus aureus and Escherichia coli. ${ }^{14}$

Abdallah and co-workers synthesized tetra-dentate macrocycle Schiff base and its complexes of $\mathrm{N}_{2} \mathrm{O}_{2}$ donor atoms with $\mathrm{Cr}$ (III) and $\mathrm{Fe}$ (III) ions. ${ }^{15}$ All compounds showed an outstanding biological activity against $S$. aureus and $E$. coli bacteria and C. albicans and A. flavus fungi. Thermal analysis indicated that all complexes have low stability due to the hydration water.

Schiff base ligands 2-bromo-4-chloro-6-[(2-piperidin-1-ylethylimino) methyl]phenol (BCP) and 2,4-dibromo-6-[(2-morpholin-4-ylethylimino) methyl]phenol (DBP) and their nickel(II) and copper(II) complexes [Ni (BCP), $\left.\left(\mathrm{CH}_{3} \mathrm{OH}\right)_{2}\right]\left(\mathrm{NO}_{3}\right)_{2}$ and $\left[\mathrm{Cu}(\mathrm{DBP})_{2}\right]$ have been prepared and characterized. The Schiff bases coordinate to the metal ions through the phenolate $\mathrm{O}$ and imine $\mathrm{N}$ atoms. ${ }^{16}$

A series of macrocycle compounds of $\mathrm{Cu}(\mathrm{II}), \mathrm{Co}(\mathrm{II}), \mathrm{Ni}(\mathrm{II})$, and $\mathrm{Zn}$ (II) prepared through the template condensation reaction of ethylene diamine and acetonyl acetone have been reported. ${ }^{17}$ These complexes have proved good antibacterial activity against some pathogenic bacteria

Two new square planar mononuclear copper(II) complexes was synthesized form of a Schiff base $N, N^{\prime}$-bis(2-hydroxynaphthylmethylidene)1,3-pentanediamine. The complexes have efficient catalytic oxidation properties on alkenes with TBHP as oxidant. ${ }^{18}$

Mohamed and co-workers has prepared tri-dentate macrocyle Schiff base and its $\mathrm{Zn}(\mathrm{II}), \mathrm{Mn}(\mathrm{II}), \mathrm{Fe}(\mathrm{III}), \mathrm{Co}(\mathrm{II}), \mathrm{Ni}(\mathrm{II})$, and $\mathrm{Cu}(\mathrm{II})$ complexes from triazine ligand with NNO donation sites towards metal ions. ${ }^{19}$ The triazine ligand and its all complexes are found to have biological activity against the desert locust Schistocerca gregaria. The thermal analysis showed neither water molecules of coordination nor hydration in the structure of these complexes.

Two new mononuclear nickel(II) and zinc(II) complexes with the zwitterionic ligand 2-bromo-6-[(3-cyclohexylammoniopropylimino)methyl] phenolate have been prepared and characterized. The complexes have from medium to effective antibacterial activities, which are interesting and deserve deeply study. ${ }^{20}$

The macrocycle complexes of $\mathrm{Ni}(\mathrm{II}), \mathrm{Cu}(\mathrm{II}), \mathrm{Zn}(\mathrm{II})$, and $\mathrm{Co}(\mathrm{II})$ have been prepared from the condensation of glyoxal and L-leucine in ethanol. ${ }^{21}$ The fluorescence and absorption spectroscopy of compounds revealed an important binding to calf thymus DNA.

The new $\mathrm{Co}(\mathrm{II})$ and $\mathrm{Ni}(\mathrm{II})$ complexes with the Schiff base derived from amoxicillin and salicylaldehyde were synthesized and characterized. The thermal degradation data of both complexes showing that the molecules of coordinated water were released with an endothermic effect and the degradation process was followed by an exothermic effect. The results also showed increase in antimicrobial activity of metal complexes. ${ }^{22}$

Nitrogen-containing macrocycles have a strong tendency to form stable complexes with transition metals and have been reported to exhibit potent antiHIV, antibacterial, and antifungal activities. ${ }^{23-26}$

Due to the growing interest in macrocycle Schiff base and their complexes, the synthesis and spectroscopic characterization of a novel tetra-azamacrocycle derived from the condensation of 3-bromopentane-2,4-dione and benzene-1,2-diamine, and its complexes with four M(II) ions, were reported. These compounds have also monitored for their anti-bacterial activity against some bacteria and fungi.

The thermal analyses have carried out in inert atmosphere of nitrogen gas. Thermo-gravimetric studies of compounds have performed to obtain information about their thermal stability, and to decide about the presence of the water molecules and the decomposition steps of their structures. Moreover, thermal analysis technique that provides extremely sensitive measurements of heat changes may be applied widely in pharmaceutical development.

The theoretical studies of molecular and electronic structures of the macrocycle and its complexes have also conducted. Molecular orbital calculations were accomplished by DFT (density functional theory) at B3LYP level with standard 6-31G (d, p) and LANL2DZ basis sets. The calculations have performed to obtain the optimized molecular geometry, charge density distribution, HOMO (highest occupied molecular orbital) and LUMO (lowest unoccupied molecular orbital) of the macrocycle and all complexes.

\section{EXPERIMENTAL}

\subsection{Chemicals and Reagents}

Benzene-1,2-diamine (Merck), $\mathrm{CoCl}_{2} .6 \mathrm{H}_{2} \mathrm{O}, \mathrm{NiCl}_{2} \cdot 6 \mathrm{H}_{2} \mathrm{O}, \mathrm{CuCl}_{2} .2 \mathrm{H}_{2} \mathrm{O}$, and $\mathrm{ZnCl}_{2} \cdot 2 \mathrm{H}_{2} \mathrm{O}$ (Merck), 3-bromopentane-2,4-dione (Aldrich), DMF (Merck), phosphorus pentoxide (Aldrich), DMSO (Aldrich), and methanol (Merck) were used as received.

\subsection{Apparatus and Physical measurements}

The ${ }^{1} \mathrm{H}$ and ${ }^{13} \mathrm{C}$ NMR spectra were recorded on a Brucker AV300 NMR spectrometer with the TMS as an internal reference. The elemental analyses were performed on a Heraeus Carlo Erba1108 elemental analyzer. The electronic spectra $\left(10^{-3} \mathrm{~mol} \mathrm{dm}^{-3}\right.$ in DMSO) were obtained with a Shimadzu UV-160 spectrophotometer. The IR spectra $\left(4000-400 \mathrm{~cm}^{-1}\right)$ were recorded 
on a Perkin-Elmer model 377 spectrometer using $\mathrm{KBr}$ pellets. Magnetic susceptibility measurements were done with a 155 Allied Research vibrating sample magnetometer at room temperature. Molar conductivities $\left(10^{-3} \mathrm{~mol}\right.$ $\mathrm{dm}^{-3}$ in DMSO) were measured with CMD 8500 Laboratory conductometer. Melting points were measured using an electrothermal Buchi 512 melting point apparatus. The metals were determined by spectrophotometric method using an AA-670 Shimadzu atomic absorption flame emission spectrophotometer. Thermal analysis (TG and DTG) were carried out on a SDT Q 600/V8.3 build 101 thermal analyzer with a heating rate of $10^{\circ} \mathrm{C} / \mathrm{min}$ using $\mathrm{N}_{2}$ atmosphere $(20$ $\mathrm{mL} / \mathrm{min}$ ). The samples were heated up at atmospheric pressure in a temperature range of $25-800^{\circ} \mathrm{C}$.

\subsection{Synthesis of macrocycle $1\left(\mathrm{C}_{22} \mathrm{H}_{22} \mathrm{~N}_{4} \mathrm{Br}_{2}\right)$}

A hot methanolic solution $(20 \mathrm{~mL})$ of 3-bromopentane-2,4-dione (1.080 g, $10 \mathrm{mmol})$ was added to the solution $(25 \mathrm{~mL})$ of benzene-1,2-diamine $(1.790$ $\mathrm{g}, 10 \mathrm{mmol})$. The solution was refluxed for 12 hours in the presence of a few drops of concentrated $\mathrm{HCl}(\mathrm{pH}=3-4)$ until a yellow solution was obtained. The solution was then placed in an ice-water container until a yellow precipitate was formed. The precipitate was filtered, washed with cold methanol and dried in vacuum to give $2.045 \mathrm{~g}(81 \%)$ of $\mathbf{1}$. Elemental analysis found $\%$ (calculated $\%$ ): C 52.59 (52.71), H 4.38 (4.22), N 11.6 (11.05). Its molecular formula was suggested to be $\mathrm{C}_{22} \mathrm{H}_{22} \mathrm{~N}_{4} \mathrm{Br}_{2}$, and was decomposed at $214{ }^{\circ} \mathrm{C}$.

IR ( $\left.\mathrm{KBr}, \mathrm{cm}^{-1}\right): 3025(\mathrm{C}-\mathrm{H}), 2983(\mathrm{C}-\mathrm{H}), 1645(\mathrm{C}=\mathrm{N}), 1455(\mathrm{C}=\mathrm{C}), 708$ (C-Br); ${ }^{1} \mathrm{H}$ NMR (300 MHz, DMSO- $\left.d, 25^{\circ} \mathrm{C}, \mathrm{ppm}\right): 2.25$ (s, 12H, 4CH $), 2.66$ (s, 2H, -CHBr), 7.40-7.84 (m, 8H, J=6.4 Hz, 2C $\left.\mathrm{H}_{4}\right) ;{ }^{13} \mathrm{C} \mathrm{NMR}(300 \mathrm{MHz}$, DMSO- $\left.d, 25^{\circ} \mathrm{C}, \mathrm{ppm}\right): 42.42\left(\mathrm{CH}_{3}\right), 62.44(\mathrm{CHBr}), 107.57(\mathrm{C}), 117.40(\mathrm{C})$ $149.31(\mathrm{C}), 161.75(\mathrm{C}=\mathrm{N}) ; \mathrm{UV}-\mathrm{Vis}\left(\mathrm{DMSO}, 25^{\circ} \mathrm{C}\right), \lambda_{\max } / \mathrm{nm}(\log \varepsilon): 265$ (3.68).

\subsection{Synthesis of the complex 2, [Co(L)Cl $\mathrm{Cl}_{2}$}

The macrocycle $1(1.0 \mathrm{~g}, 2 \mathrm{mmol})$ was dissolved in $20 \mathrm{~mL}$ of hot methanol in a flask. A solution of $\mathrm{CoCl}_{2} \cdot 6 \mathrm{H}_{2} \mathrm{O}(476 \mathrm{mg}, 2 \mathrm{mmol})$ in $15 \mathrm{ml}$ methano was then gradually added to above solution with stirring, a colour change occurred and a pale green precipitate was formed. To assure the completion of the reaction, the mixture was then refluxed for a further 5 hours on a hot plate. On cooling, the precipitated complex was filtered off, washed with methanol, and dried in vacuum to give $1.10 \mathrm{~g}(87 \%)$ of 2 . Elemental analysis found \% (calculated \%): C 41.17 (41.35), H 3.48 (3.35), N 8.86 (8.71), and Co 9.34 (9.54). Its molecular formula was suggested to be $\mathrm{C}_{22} \mathrm{H}_{22} \mathrm{Br}_{2} \mathrm{Cl}_{2} \mathrm{CoN}_{4}$, and was decomposed at $246{ }^{\circ} \mathrm{C}$.

IR $\left(\mathrm{KBr}, \mathrm{cm}^{-1}\right): 3032(\mathrm{C}-\mathrm{H}), 2985(\mathrm{C}-\mathrm{H}), 1620(\mathrm{C}=\mathrm{N}), 1450(\mathrm{C}=\mathrm{C}), 710$ (C-Br), $453(\mathrm{Co}-\mathrm{N})$; UV-Vis (DMSO, $\left.25^{\circ} \mathrm{C}\right), \lambda_{\max } / \mathrm{nm}(\log \varepsilon): 282$ (3.77), 350 (1.74), 528 (1.94), 795 (1.92); Magnetic moment: 4.96 B.M.

\subsection{Synthesis of the complexes 3,4 and 5}

The same procedure as explained above, was used for the synthesis of the complexes $\mathbf{3}, \mathbf{4}$ and $\mathbf{5}$.

The complex 3 was obtained as a green precipitate with a yield of $90.5 \%$. Elemental analysis found \% (calculated \%): C 41.80 (42.00), H 3.48 (3.38), $\mathrm{N} 8.87$ (8.72), and $\mathrm{Ni} 9.26$ (9.46). Its molecular formula was suggested to be $\mathrm{C}_{22} \mathrm{H}_{22} \mathrm{Br}_{2} \mathrm{Cl}_{2} \mathrm{NiN}_{4}$ and was decomposed at $257^{\circ} \mathrm{C}$.

IR $\left(\mathrm{KBr}, \mathrm{cm}^{-1}\right): 3035(\mathrm{C}-\mathrm{H}), 2988(\mathrm{C}-\mathrm{H}), 1628(\mathrm{C}=\mathrm{N}), 1452(\mathrm{C}=\mathrm{C}), 712$ (C-Br), $458(\mathrm{Ni}-\mathrm{N})$; UV-Vis (DMSO, $\left.25^{\circ} \mathrm{C}\right), \lambda_{\max } / \mathrm{nm}(\log \varepsilon): 274(3.60), 410$ (2.03), 650 (1.89), 1050 (1.92); Magnetic moment: 3.18 B.M

The complex 4 was obtained as a blue precipitate with a yield of $86 \%$. Elemental analysis found \% (calculated \%): C 41.48 (41.63), H 3.46 (3.22), $\mathrm{N} 8.80$ (8.67), and $\mathrm{Cu} 9.98$ (10.12). Its molecular formula was proposed to be $\mathrm{C}_{22} \mathrm{H}_{22} \mathrm{Br}_{2} \mathrm{Cl}_{2} \mathrm{CuN}$ and was decomposed at $251^{\circ} \mathrm{C}$.

IR (KBr, cm $\left.{ }^{-1}\right): 3044(\mathrm{C}-\mathrm{H}), 2980(\mathrm{C}-\mathrm{H}), 1625(\mathrm{C}=\mathrm{N}), 1458(\mathrm{C}=\mathrm{C}), 710$ (C-Br), $455(\mathrm{Cu}-\mathrm{N})$; UV-Vis (DMSO, $\left.25^{\circ} \mathrm{C}\right), \lambda_{\text {max }} / \mathrm{nm}(\log \varepsilon): 298$ (3.64), 560 (2.03), 605 (2.09); Magnetic moment: 1.96 B.M.

The complex $\mathbf{5}$ was obtained as a pale brown precipitate with a yield of $80 \%$. Elemental analysis found \% (calculated \%): C 41.35 (41.52), H 3.44 (3.35), N 8.77 (8.94), and $\mathrm{Zn} 10.26$ (10.10). Its molecular formula was proposed to be $\mathrm{C}_{22} \mathrm{H}_{22} \mathrm{Br}_{2} \mathrm{Cl}_{2} \mathrm{ZnN}_{4}$ and was decomposed at $297^{\circ} \mathrm{C}$

IR (KBr, cm $\left.{ }^{-1}\right): 3038(\mathrm{C}-\mathrm{H}), 2982(\mathrm{C}-\mathrm{H}), 1626(\mathrm{C}=\mathrm{N}), 1450(\mathrm{C}=\mathrm{C}), 713$ (C-Br), 456 (Zn-N); ${ }^{1} \mathrm{H}$ NMR (300 MHz, DMSO- $d$, $\left.25^{\circ} \mathrm{C}, \mathrm{ppm}\right): 2.35$ (s, 12H, $\left.4 \mathrm{CH}_{3}\right), 2.64(\mathrm{~s}, 2 \mathrm{H},-\mathrm{CHBr}), 7.64-7.91\left(\mathrm{~m}, 8 \mathrm{H}, \mathrm{J}=6.3 \mathrm{~Hz}, 2 \mathrm{C}_{6} \mathrm{H}_{4}\right) ;{ }^{13} \mathrm{C} \mathrm{NMR}$ $\left(300 \mathrm{MHz}, \mathrm{DMSO}-d, 25^{\circ} \mathrm{C}, \mathrm{ppm}\right): 41.83\left(\mathrm{CH}_{3}\right), 62.91(\mathrm{CHBr}), 106.85(\mathrm{C})$, $116.62(\mathrm{C}), 150.45(\mathrm{C}), 155.62(\mathrm{C}=\mathrm{N})$; UV-Vis $\left(\mathrm{DMSO}, 25^{\circ} \mathrm{C}\right), \lambda_{\max } / \mathrm{nm}(\mathrm{Log}$ $\varepsilon): 288(3.58)$

\subsection{Biological activity monitoring}

A filter paper disk $(8 \mathrm{~mm})$ was transferred into $250 \mathrm{~mL}$ flasks including $20 \mathrm{~mL}$ of working volume of tested solution $\left(100 \mu \mathrm{g} \mathrm{cm} \mathrm{cm}^{-3}\right)$. All flasks were autoclaved for $20 \mathrm{~min}$ at $125{ }^{\circ} \mathrm{C}$ : agar media surfaces were incubated with two Gram positive (Bacillus subtilis and Staphylococcus aureus) and two Gram negative (Escherichia coli and Pseudomonas aeruginosa) bacteria and two fungi (Sacchromyces cerevisiae and Candida albicans) were investigated using two existing antibacterial drugs namely ciprofloxacin and amphotericin B. Then, it transferred to a saturated disk with a tested solution in the center of Petri dish. Ultimately, all these Petri dishes were incubated at $25{ }^{\circ} \mathrm{C}$ for $48 \mathrm{~h}$ where clear or inhibition zones were detected periphery each disk. Control flask of the experiment was designed to accomplish under the same condition described previously for each microorganism and by subtracting the diameter of inhibition zone resulting with DMF from that obtained in each case. Therefore antibacterial activity could be computed. All experiments were performed as triplicate.

\subsection{Computational details}

The geometry optimizations of the macrocycle $\mathbf{1}$ and its complexes were carried out at gradient corrected DFT using B3LYP combined with 6-31G (d, p) and LANL2DZ basis sets by GAUSSIAN $03 \mathrm{~W} .^{27,28}$ The studied complexes are characterized as minima in their potential energy surface.

Molecular frontier orbitals: HOMO and LUMO, and the optimized structures were projected with Gaussian view. Using HOMO and LUMO orbital energies, the ionization energy and electron affinity can be expressed as: $I=-E_{\text {номо }}, A=-E_{\text {LUмо }}$, respectively. The hardness, $\eta$ and chemical potential, $\mu$ were given by the following relations: $\eta=(I-A) / 2$ and $\mu=-(I+A) / 2$, respectively. ${ }^{29}$ Electronegativity can be expressed as: $\chi=-\mu$.

\section{RESULTS AND DISCUSSION}

The macrocycle 1 was prepared according to a similar previous procedure, ${ }^{30,31}$ it was synthesized from condensation a mixture of 3-bromopentane-2,4-dione and benzene-1,2-diamine in MeOH (Scheme 1).

In the next step, four complexes of macrocycle 1 were prepared by its reaction with $\mathrm{CoCl}_{2} \cdot 6 \mathrm{H}_{2} \mathrm{O}, \mathrm{NiCl}_{2} \cdot 6 \mathrm{H}_{2} \mathrm{O}, \mathrm{CuCl}_{2} .2 \mathrm{H}_{2} \mathrm{O}$, and $\mathrm{ZnCl}_{2} .2 \mathrm{H}_{2} \mathrm{O}$ in $\mathrm{MeOH}$. Thus the complexes may be formulated as $\left[\mathrm{M}(\mathrm{L}) \mathrm{Cl}_{2}\right]$ \{where $\mathrm{M}=$ $\mathrm{Co}$ (II) 2, $\mathrm{Ni}$ (II) 3, $\mathrm{Cu}$ (II) 4, and $\mathrm{Zn}$ (II) 5, respectively\} .

The molar conductance of the complexes $2,3,4$ and 5 were obtained to be $22,18,23$, and $25 \Omega^{-1} \mathrm{~cm}^{2} \mathrm{~mol}^{-1}$, respectively. This revealed that all of the four complexes are non-electrolyte. ${ }^{32}$ Therefore, based on elemental analysis and molar conductance data, all complexes have $\left[\mathrm{M}(\mathrm{L}) \mathrm{Cl}_{2}\right]$ formula in which two chloride ions are placed on the coordination layer.

\subsection{IR spectra}

The characteristic IR bands observed for macrocycle $\mathbf{1}$ and its complexes are assigned and reported in the experimental section. The disappearance of two bands at $1720 \mathrm{~cm}^{-1}, v(\mathrm{C}=\mathrm{O})$ and $3335 \mathrm{~cm}^{-1}, v\left(\mathrm{NH}_{2}\right)$, and appearance of a strong band at $1645 \mathrm{~cm}^{-1}, v(\mathrm{C}=\mathrm{N})$, in 1 confirms an effective Schiff base condensation of the amino groups with the keto groups. ${ }^{33}$ The band due to $v(\mathrm{C}=\mathrm{N})$ observed at $1645 \mathrm{~cm}^{-1}$ in the case of 1 shows a negative shift of 17-25 $\mathrm{cm}^{-1}$ in the all complexes. This suggests the coordination of azomethine groups of 1 to the metal ion(II). ${ }^{34}$

This is also supported by the appearance of a new band at around 455 $\mathrm{cm}^{-1}$ in the all complexes, which has been attributed to the $v(\mathrm{M}-\mathrm{N})$ stretching vibrations. $^{35}$ Eventually, four band observed at 3025, 2983, 1455 and 708 $\mathrm{cm}^{-1}$ due to aromatic $v(\mathrm{C}-\mathrm{H})$, aliphatic $v(\mathrm{C}-\mathrm{H})$, aromatic $v(\mathrm{C}=\mathrm{C})$ and $v(\mathrm{C}-\mathrm{Br})$ stretching vibrations of $\mathbf{1}$, respectively, appeared nearly in the same places for the all complexes. ${ }^{36}$

\subsection{NMR spectra}

The ${ }^{1} \mathrm{H}$ NMR spectrum of $\mathbf{1}$ exhibits a singlet at $2.25 \mathrm{ppm}\left(\mathrm{s}, 12 \mathrm{H}, 4 \mathrm{CH}_{3}\right)$ due to four methyl groups, and another singlet at $2.66 \mathrm{ppm}(\mathrm{s}, 2 \mathrm{H},-\mathrm{CHBr})$ due to the proton which is located in the vicinity of bromine atom. ${ }^{37} \mathrm{~A}$ multiple signal at 7.40-7.84 ppm is assigned to the aromatic ring protons. These signals indicate the presence of three types of protons in $1 .{ }^{38} \mathrm{All}$ signals of ${ }^{1} \mathrm{H}$ NMR spectrum were observed for $\mathbf{5}$ appeared nearly in the same places of $\mathbf{1}$.

These are also confirmed through the ${ }^{13} \mathrm{C}$ NMR spectra, which show six signals for the 22 carbon atoms of 1 . The ${ }^{13} \mathrm{C}$ NMR spectrum of 1 showed three resonances at $107.57(\mathrm{C} 2, \mathrm{C} 5, \mathrm{C} 11, \mathrm{C} 14), 117.40(\mathrm{C} 3, \mathrm{C} 4, \mathrm{C} 12, \mathrm{C} 13)$ and $149.31 \mathrm{ppm}(\mathrm{C} 1, \mathrm{C} 6, \mathrm{C} 10, \mathrm{C} 15)$ due to three different carbons of aromatic rings. ${ }^{39}$ The chemical shift for the carbon $\mathrm{C} 1$ bonded to the nitrogen of the 
azomethine group observed downfield with respect to the other two type's carbon of aromatic ring. ${ }^{40}$ The signal observed at 42.42 ppm corresponding to methyl groups, and another signal at $62.44 \mathrm{ppm}$ is due to carbon bonded to $\mathrm{Br}$ atom which also appearance in downfield region. ${ }^{41}$

The signal due to carbon atom of the azomethine group $(\mathrm{C}=\mathrm{N})$ of $\mathbf{1}$ is observed at low field at 161.75 ppm. ${ }^{42}$ This resonance shifted up-field to 155.62 ppm in 5. Therefore the shielding effects on this signal in its complexes suggests coordination of nitrogen donor atoms of the azomethine groups of the macrocycle ring to the $\mathrm{M}(\mathrm{II})$ ions.<smiles>Nc1ccccc1N</smiles>

2

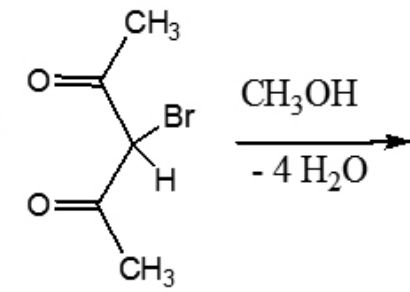

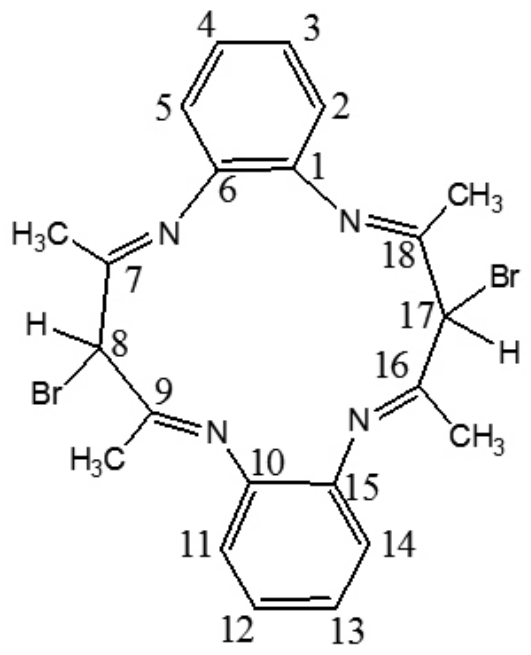

Scheme 1 Reaction for preparation of the macrocycle 1.

\subsection{Electronic spectra}

The electronic spectra of $\mathbf{1}$ and its complexes (Figures 1S-5S in supplementary materials) exhibited absorption bands in the region $265-298 \mathrm{~nm}$ which can be attributed to $\pi \rightarrow \pi^{*}$ intra-ligand transition of azomethine groups and benzene rings incorporated in the skeleton of macrocycle $1 .^{43}$

The spectra of all complexes represented another types of transitions which are different from the free macrocycle 1. All the complexes displayed absorption in the region $350-1050 \mathrm{~nm}$ which can be assigned to d-d transitions involving the metal orbitals. ${ }^{44}$

The magnetic moment of 4.16 B.M. for 2 is representative of a high-spin octahedral geometry for the $\mathrm{Co}(\mathrm{II})$ ion. ${ }^{45}$ Three absorption bands of medium intensity were observed at $795 \mathrm{~nm}\left(12580 \mathrm{~cm}^{-1}\right), 528 \mathrm{~nm}\left(18940 \mathrm{~cm}^{-1}\right)$ and 350 $\mathrm{nm}\left(28570 \mathrm{~cm}^{-1}\right)$ for 2 that can be attributed to ${ }^{4} \mathrm{~T}_{1 \mathrm{~g}} \rightarrow{ }^{4} \mathrm{~T}_{2 \mathrm{~g}}(\mathrm{~F}),{ }^{4} \mathrm{~T}_{1 \mathrm{~g}} \rightarrow{ }^{4} \mathrm{~T}_{1 \mathrm{~g}}(\mathrm{P})$, and ${ }^{4} \mathrm{~T}_{1} \rightarrow{ }^{4} \mathrm{~A}_{2}(\mathrm{~F})$ transitions respectively. ${ }^{46}$ The splitting energy, Racah parameter, and nephelauxetic parameter for 2 were calculated to be $15990,635 \mathrm{~cm}^{-1}$ and 0.58 . The value of $\beta$ in this case indicates that the covalent character of metalligand sigma bond is very high. Therefore these absorption bands together with the magnetic moment are attributable to an octahedral geometry around the $\mathrm{Co}(\mathrm{II})$ ion.

The bands were observed at the regions $1050 \mathrm{~nm}\left(9525 \mathrm{~cm}^{-1}\right), 650 \mathrm{~nm}$ $\left(15385 \mathrm{~cm}^{-1}\right)$ and $410 \mathrm{~nm}\left(24390 \mathrm{~cm}^{-1}\right)$ for 3 were attributed to ${ }^{3} \mathrm{~A}_{2 g} \rightarrow{ }^{3} \mathrm{~T}_{2 g}$, ${ }^{3} \mathrm{~A}_{2 g} \rightarrow{ }^{3} \mathrm{~T}_{1 g}(\mathrm{~F})$, and ${ }^{3} \mathrm{~A}_{2 g} \rightarrow{ }^{3} \mathrm{~T}_{2 g}(\mathrm{P})$ transition respectively. ${ }^{47}$ The splitting energy, Racah parameter and nephelauxetic parameter for $\mathbf{3}$ were obtained 9525 , $745 \mathrm{~cm}^{-1}$ and 0.72 respectively. The magnetic moment of 2.98 B.M. for 3 clearly confirm the presence of two unpaired electrons in a pseudo-octahedral environment of $\mathrm{Ni}(\mathrm{II})$, in agreement with a high-spin configuration $\left(\mathrm{t}_{2} \mathrm{~g}\right)^{6}\left(\mathrm{e}_{2} \mathrm{~g}\right)^{2}$ as was also observed in similar systems for Ni(II) complexes. ${ }^{48}$ Therefore, an octahedral geometry is suggested for $3 .{ }^{49}$

An electronic transition of type ${ }^{2} \mathrm{E} \rightarrow{ }^{2} \mathrm{~T}$ is expected for $\mathrm{Cu}$ (II) with $\left(\mathrm{t}_{2} \mathrm{~g}\right)^{6}(\mathrm{eg})^{3}$ configuration. ${ }^{50}$ Appearance of two absorption bands with near energy displayed which $\mathrm{Cu}(\mathrm{II})$ compounds undergoing John-Teller distortion. Therefore the bands at the regions $605 \mathrm{~nm}\left(16530 \mathrm{~cm}^{-1}\right)$ and $560 \mathrm{~nm}\left(17860 \mathrm{~cm}^{-1}\right)$ for 4 were attributed to the ${ }^{2} \mathrm{~B}_{1 g} \rightarrow{ }^{2} \mathrm{~B}_{2 g}$ and ${ }^{2} \mathrm{~B}_{1 g} \rightarrow{ }^{2} \mathrm{E}_{g}$ transitions respectively. ${ }^{51}$ The magnetic moment of 1.96 B.M. for 4 is in agreement with that obtained for distorted octahedral $\mathrm{Cu}$ (II) complexes. ${ }^{52}$

The complex 5 is diamagnetic. As it is expected due to the $\left(\mathrm{t}_{2} g\right)^{6}(\mathrm{e} g)^{4}$ configuration of $\mathrm{Zn}$ (II) ion, electronic spectra of $\mathbf{5}$ did not exhibit any $\mathrm{d}$-d transition, but only an intra-ligand transition absorption is obtained at $288 \mathrm{~nm}$. By analogy with those explained for the all complexes containing $\mathrm{N}_{4}$ donor of 1 and two chloride ions and according to the empirical formula and molar conductance of this complex, one can suggest an octahedral geometry for $\mathbf{5}$.

\subsection{Thermal analysis}

Thermal gravimetric analysis offer information about the thermal stability of the complex as well as whether the water molecules are in the inner or outer coordination sphere of the central metal ion..$^{53}$

The TG and DTG data of $\mathbf{1}$ and its complexes which were recorded under a nitrogen atmosphere are given in Table 1.

The macrocycle 1 represents a two-step thermolytic template while its complexes decompose in three stairs. The first step decomposition of $\mathbf{1}$ occurred at the temperature range $187-273{ }^{\circ} \mathrm{C}$ which is associated with a DTG peak at $255^{\circ} \mathrm{C}$. This corresponds to the loss of organic moiety $\left(\mathrm{C}_{6} \mathrm{H}_{4} \mathrm{~N}_{2}\right)$ with a mass loss of $40.5 \%$ (calcd. $41.4 \%$ ). The second step of the decomposition happened in the range of $274-456{ }^{\circ} \mathrm{C}$ relating to a DTG peak at $394{ }^{\circ} \mathrm{C}$. This correlates with the loss of organic moiety $\left(\mathrm{C}_{5} \mathrm{H}_{7} \mathrm{Br}\right)$ with a mass loss of $59.5 \%$ (calcd. 58.6\%). It can be noticed that TG curve of complexes exhibits no mass loss up to $231{ }^{\circ} \mathrm{C}$, indicating the absence of water molecules in coordination sphere, and also conforms the stability of the complexes up to $231^{\circ} \mathrm{C}$.

The thermo-gram of $\mathbf{2}$ displayed three decomposition stages. The first step of the decomposition at the temperature range $242-318^{\circ} \mathrm{C}$ is associated with a DTG peak at $265^{\circ} \mathrm{C}$ corresponding to the loss of two chloride ions as $\mathrm{HCl}$ with a mass loss of $12.5 \%$ (calcd. 11.6\%). A second and third decomposition step of $\mathbf{2}$ is similar with the two-step decomposition of $\mathbf{1}$. The second decomposition step took place in the range of $319-445^{\circ} \mathrm{C}$ that is associated with a DTG peak at $372{ }^{\circ} \mathrm{C}$. This corresponds to the loss of two groups $\mathrm{C}_{6} \mathrm{H}_{4} \mathrm{~N}_{2}$ with a mass loss of $32.5 \%$ (calcd. $32.9 \%$ ). The third decomposition step happened in the range of $446-592{ }^{\circ} \mathrm{C}$ shows a DTG peak at $488{ }^{\circ} \mathrm{C}$, which corresponds to the loss of two groups $\mathrm{C}_{5} \mathrm{H}_{6} \mathrm{Br}$ with a mass loss of $45.0 \%$ (calcd. $46.2 \%$ ). At the end of decomposition process, the resulting residue is metallic cobalt, ${ }^{54}$ with a mass of $10.0 \%$ (calcd. $9.3 \%$ ).

The thermo-gram of complexes $\mathbf{3}, \mathbf{4}$ and $\mathbf{5}$ which are similar to $\mathbf{2}$ display three decomposition steps. The complexes $\mathbf{3 , 4}$ and $\mathbf{5}$ are stable up to 250,231 and $244{ }^{\circ} \mathrm{C}$ respectively. The first step of the decomposition in the range of 250-342 ${ }^{\circ} \mathrm{C}$ for $\mathbf{3}, 231-310^{\circ} \mathrm{C}$ for $\mathbf{4}$, and $244-352{ }^{\circ} \mathrm{C}$ for $\mathbf{5}$ are associated with DTG peaks at 305,285 , and $308^{\circ} \mathrm{C}$. This shows the loss of two chloride ions as $\mathrm{HCl}$ with a mass loss of $12.0,12.0$, and $12.5 \%$ (calcd. 11.6, 11.5 and $11.4 \%$ ) respectively.

The second step of the decomposition occurred in the range of $343-482{ }^{\circ} \mathrm{C}$ for $\mathbf{3}, 311-493{ }^{\circ} \mathrm{C}$ for $\mathbf{4}$, and $353-495{ }^{\circ} \mathrm{C}$ for $\mathbf{5}$ relating to DTG peaks at 412 , 432 , and $438{ }^{\circ} \mathrm{C}$. This can be attributed to the loss of two groups $\mathrm{C}_{6} \mathrm{H}_{4} \mathrm{~N}_{2}$ with a mass loss of $33.5,33.0$, and $33.0 \%$ (calcd. $32.9,32.7$ and $32.6 \%$ ) respectively.

The third step of the decomposition happed in the range of $483-575^{\circ} \mathrm{C}$ for 3, $494-604{ }^{\circ} \mathrm{C}$ for $\mathbf{4}$, and $496-608^{\circ} \mathrm{C}$ for $\mathbf{5}$ relating DTG peaks at 520,542 , and 
$552{ }^{\circ} \mathrm{C}$. This corresponds to the loss of two groups $\mathrm{C}_{5} \mathrm{H}_{6} \mathrm{Br}$ with a mass loss of $46.0,46.5 .0$, and $45.5 \%$ (calcd. $46.2,45.9$ and $45.8 \%$ ) respectively. By the end of decomposition, what are left are nickel, copper, and zinc with a mass of 10.0, 8.5, and 9.0\% (calcd. 9.3, 9.9, and 10.2\%) for complexes $\mathbf{3}, \mathbf{4}$ and 5 respectively.

\subsection{Biological activity}

The macrocycle $\mathbf{1}$ and its complexes have been screened for both antibacterial and antifungal activities. The results of the microbial screening of $\mathbf{1}$ and its all complexes are listed in Table 2.

Table 1 The Thermo-gravimetric data (TG and DTG) of macrocycle 1 and its complexes.

\begin{tabular}{|c|c|c|c|c|}
\hline Compounds & TG range $/{ }^{\circ} \mathrm{C}$ & $\mathrm{DTG}_{\max } /{ }^{\circ} \mathrm{C}$ & \% Mass loss (Calcd.) & Assignments \\
\hline $\mathbf{1}\left(\mathrm{C}_{22} \mathrm{H}_{22} \mathrm{~N}_{4} \mathrm{Br}_{2}\right)$ & $\begin{array}{l}187-273 \\
274-456\end{array}$ & $\begin{array}{l}255 \\
394\end{array}$ & $\begin{array}{l}40.5(41.4) \\
53.5(54.1)\end{array}$ & $\begin{array}{l}-2 \mathrm{C}_{6} \mathrm{H}_{4} \mathrm{~N}_{2} \\
-2 \mathrm{C}_{5} \mathrm{H}_{7} \mathrm{Br}\end{array}$ \\
\hline $2\left[\mathrm{Co}\left(\mathrm{C}_{22} \mathrm{H}_{22} \mathrm{~N}_{4} \mathrm{Br}_{2}\right) \mathrm{Cl}_{2}\right]$ & $\begin{array}{l}242-318 \\
319-445 \\
446-592\end{array}$ & $\begin{array}{l}265 \\
372 \\
488\end{array}$ & $\begin{array}{c}12.5(11.6) \\
32.5(32.9) \\
45.0(46.2) \\
10.0(9.3)\end{array}$ & $\begin{array}{c}-2 \mathrm{HCl} \\
-2 \text { organic moiety, } \mathrm{C}_{6} \mathrm{H}_{4} \mathrm{~N}_{2} \\
-2 \text { groups } \mathrm{C}_{5} \mathrm{H}_{6} \mathrm{Br} \\
\text { residue: } \mathrm{Co}\end{array}$ \\
\hline $3\left[\mathrm{Ni}\left(\mathrm{C}_{22} \mathrm{H}_{22} \mathrm{~N}_{4} \mathrm{Br}_{2}\right) \mathrm{Cl}_{2}\right]$ & $\begin{array}{l}250-342 \\
343-482 \\
483-575\end{array}$ & $\begin{array}{l}305 \\
412 \\
520\end{array}$ & $\begin{array}{c}12.0(11.6) \\
33.5(32.9) \\
46.0(46.2) \\
8.5(9.3)\end{array}$ & $\begin{array}{c}-2 \mathrm{HCl} \\
-2 \text { organic moiety, } \mathrm{C}_{6} \mathrm{H}_{4} \mathrm{~N}_{2} \\
-2 \text { groups } \mathrm{C}_{5} \mathrm{H}_{6} \mathrm{Br} \\
\text { residue: } \mathrm{Ni}\end{array}$ \\
\hline $4\left[\mathrm{Cu}\left(\mathrm{C}_{22} \mathrm{H}_{22} \mathrm{~N}_{4} \mathrm{Br}_{2}\right) \mathrm{Cl}_{2}\right]$ & $\begin{array}{l}231-310 \\
311-493 \\
494-604\end{array}$ & $\begin{array}{l}285 \\
432 \\
542\end{array}$ & $\begin{array}{c}12.0(11.5) \\
33.0(32.7) \\
46.5(45.9) \\
8.5(9.9)\end{array}$ & $\begin{array}{c}-2 \mathrm{HCl} \\
-2 \text { organic moiety, } \mathrm{C}_{6} \mathrm{H}_{4} \mathrm{~N}_{2} \\
-2 \text { groups } \mathrm{C}_{5} \mathrm{H}_{6} \mathrm{Br} \\
\text { residue: } \mathrm{Cu}\end{array}$ \\
\hline $5\left[\mathrm{Zn}\left(\mathrm{C}_{22} \mathrm{H}_{22} \mathrm{~N}_{4} \mathrm{Br}_{2}\right) \mathrm{Cl}_{2}\right]$ & $\begin{array}{l}244-352 \\
353-495 \\
496-608\end{array}$ & $\begin{array}{l}308 \\
438 \\
552\end{array}$ & $\begin{array}{c}12.5(11.4) \\
33.0(32.6) \\
45.5(45.8) \\
9.0(10.2)\end{array}$ & $\begin{array}{c}-2 \mathrm{HCl} \\
-2 \text { organic moiety, } \mathrm{C}_{6} \mathrm{H}_{4} \mathrm{~N}_{2} \\
-2 \text { groups } \mathrm{C}_{5} \mathrm{H}_{6} \mathrm{Br} \\
\text { residue: } \mathrm{Zn}\end{array}$ \\
\hline
\end{tabular}

Table 2 The antimicrobial activity of macrocycle $\mathbf{1}(\mathrm{L})$ and its complexes.

\begin{tabular}{|c|c|c|c|c|c|c|}
\hline \multirow{2}{*}{ Compounds } & \multicolumn{7}{|c|}{ Diameter of inhibition zone/ mm } \\
\cline { 2 - 7 } & S.aurous & B.subtilis & E.coli & P.aeruginosa & S.cerevisiae & C.albicans \\
\hline macrocycle 1 & - & - & - & - & - & - \\
\hline$\left[\mathrm{Co}(\mathrm{L}) \mathrm{Cl}_{2}\right] \mathbf{2}$ & 8 & 12 & - & - & - & - \\
\hline$\left[\mathrm{Ni}(\mathrm{L}) \mathrm{Cl}_{2}\right] \mathbf{3}$ & 11 & 13 & - & - & 17 & 20 \\
\hline$\left[\mathrm{Cu}(\mathrm{L}) \mathrm{Cl}_{2}\right] \mathbf{4}$ & 28 & 26 & 28 & 30 & 9 & 11 \\
\hline$\left[\mathrm{Zn}(\mathrm{L}) \mathrm{Cl}_{2}\right] \mathbf{5}$ & - & - & 19 & 17 & - & - \\
\hline $\mathrm{Ciprofloxacin}$ & 32 & 34 & 35 & 32 & 18 & 22 \\
\hline Amphotericin-B & - & - & - & - & & 2 \\
\hline
\end{tabular}

The antimicrobial monitoring data represented that 1 does not exhibit any antimicrobial activity. The complexes $\mathbf{2}$ and $\mathbf{3}$ displayed antibacterial activities against Gram-positive bacteria (B. subtilis and $S$. aurous), while complex 5 demonstrated antibacterial activity against Gram-negative bacteria $(E$. coli and $P$. aeruginosa), and antifungal activity against fungi $(S$. cerevisiae and $C$. albicans). The complex 4 also exhibited good activities against Gram-positive and Gram-negative bacteria and fungi. Albeit it has lower antimicrobial activity compared to standard antibiotics Ciprofloxacin and antifungal drug Amphotericin-B.

The results from this investigation have also demonstrated that coordination of metals to macrocycle serves to amend the antimicrobial activity of the ligand..$^{55}$

\subsection{Molecular modeling}

The optimized molecular structures with minimum energies and its atom numbering obtained from the quantum chemical calculations for $\mathbf{1}$ and $\mathbf{2}$ are shown in Figures 1 and $\mathbf{2}$ respectively. The selected bond lengths and bond angles of $\mathbf{1}$ and its complexes are listed in Table $\mathbf{3}$.

As can be seen, based on the coordination number 6 and bond angles closely to $90^{\circ}$, all complexes have octahedral geometry with slight distortion. The two axial positions are occupied by chloride ions, while the equatorial positions are being occupied by nitrogen atoms of the azomethine groups of $\mathbf{1}$

The N13-Co-N14, N14-Co-N23, N23-Co-N24 and N24-Co-N13 bond angles in 2 have values of $85.85,95.64,86.85$ and $92.66^{\circ}$ respectively. The bond angle $\mathrm{Cl} 27-\mathrm{Co}-\mathrm{Cl} 28$ is founding to be $177.48^{\circ}$. These results confirmed our prediction that $\mathbf{2}$ have distorted octahedral coordination geometry. Upon coordination, the $\mathrm{C}=\mathrm{N}$ bond lengths of $\mathbf{1}$ are affected by the coordination to the metal ion, namely C21-N23, C16-N14, C22-N24 and C15-N13 bonds in 2 are slightly increased to be $1.334,1.336,1.334$ and $1.333 \AA$ respectively. The other bond distances in $\mathbf{1}$ either are affected slightly or not affected at all by the coordination to the metal ion. The bond distances of the coordinating atoms with the central metal atom in 2 are found $\mathrm{Co}-\mathrm{N} 13=1.929 \AA, \mathrm{Co}-\mathrm{N} 14=1.953$ $\AA, \mathrm{Co}-\mathrm{N} 23=1.951 \AA, \mathrm{Co}-\mathrm{N} 24=1.928 \AA$, and $\mathrm{Co}-\mathrm{Cl} 27=2.382 \AA, \mathrm{Co}-\mathrm{Cl} 28=$ $2.378 \AA$. These values are in good agreement with the observed X-ray data for Co(II) complexes with Schiff base ligand and chloride ion. ${ }^{56}$ The calculations showed that complexes $\mathbf{3}, \mathbf{4}$ and $\mathbf{5}$ have similar geometry to that of $\mathbf{2}$. 


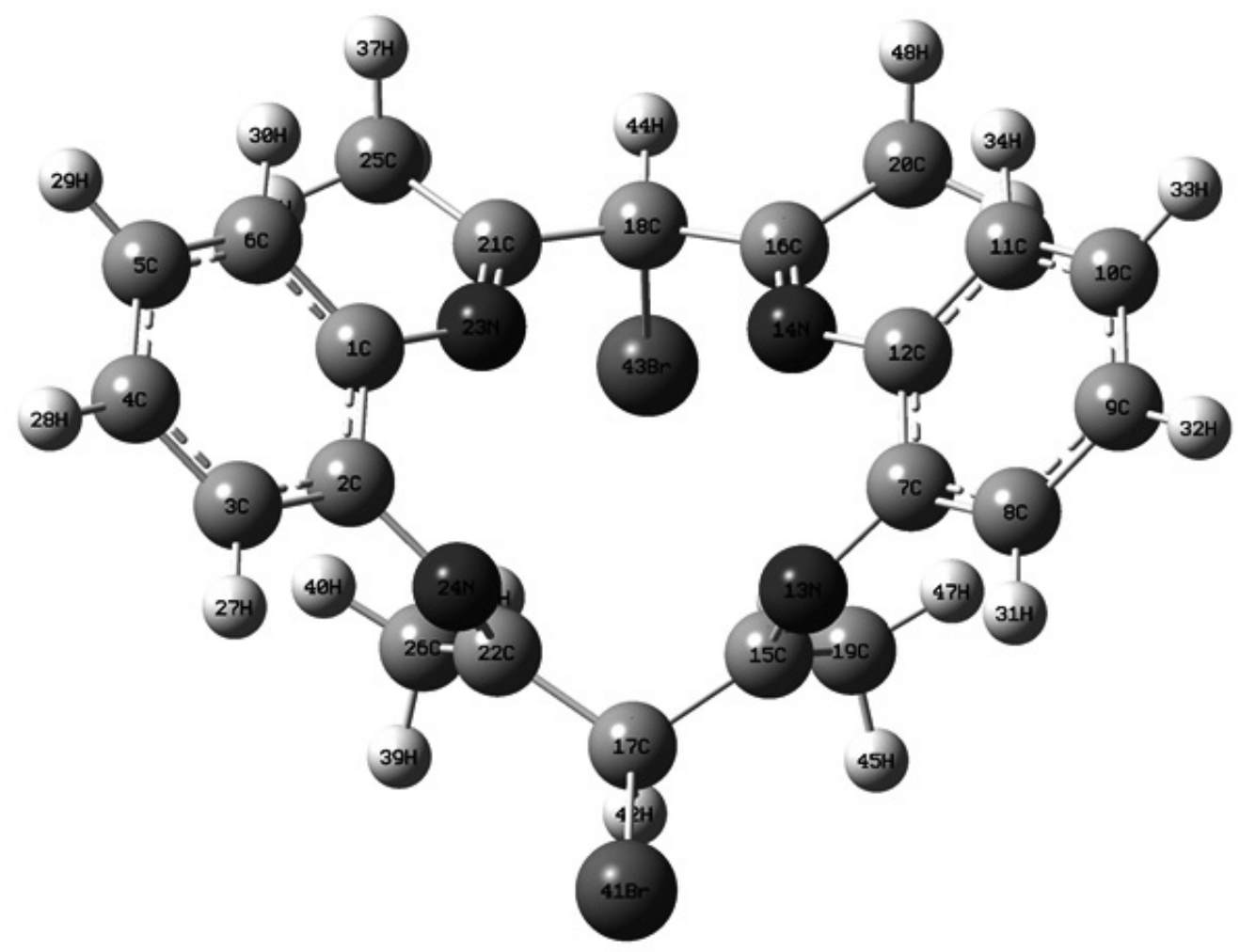

Figure 1 The optimized geometry of the macrocycle 1 .

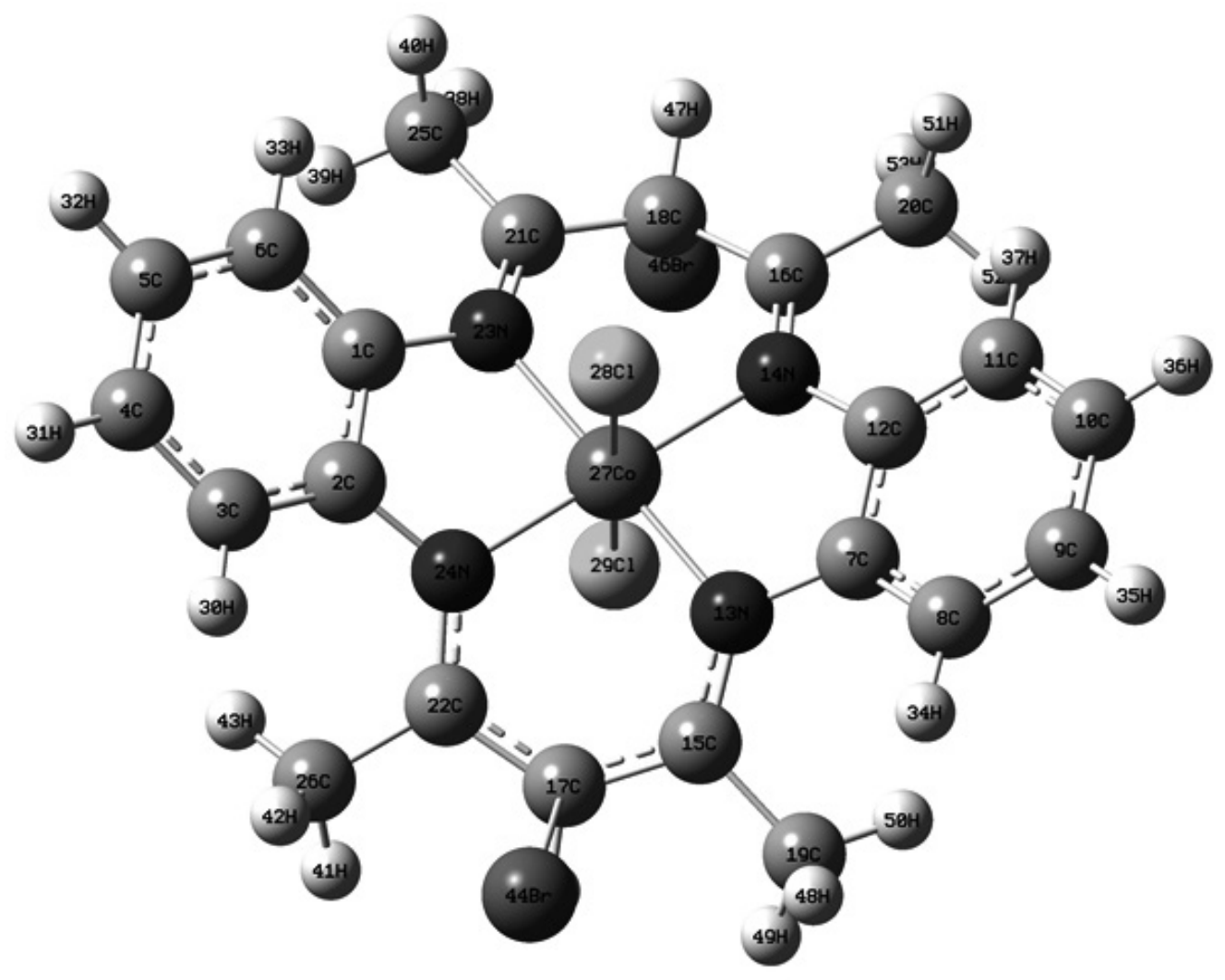

Figure 2 The optimized geometry of the complex 2 . 
Table 3 Selected optimized geometry parameters of $\mathbf{1}(\mathrm{L})$ and its complexes (bond length in Angstroms and bong angle in degrees).

\begin{tabular}{|c|c|c|c|c|c|}
\hline Parameters & $\mathrm{L}$ & {$\left[\mathrm{Co}(\mathrm{L}) \mathrm{Cl}_{2}\right]$} & {$\left[\mathrm{Ni}(\mathrm{L}) \mathrm{Cl}_{2}\right]$} & {$\left[\mathrm{Cu}(\mathrm{L}) \mathrm{Cl}_{2}\right]$} & {$\left[\mathrm{Zn}\left(\mathrm{L} \mathrm{Cl}_{2}\right]\right.$} \\
\hline Bond length & & & & & \\
\hline C21-N23 & 1.295 & 1.334 & 1.328 & 1.365 & 1.354 \\
\hline C16-N14 & 1.294 & 1.336 & 1.327 & 1.361 & 1.356 \\
\hline C22-N24 & 1.286 & 1.334 & 1.328 & 1.351 & 1.330 \\
\hline C15-N13 & 1.288 & 1.333 & 1.326 & 1.353 & 1.331 \\
\hline C18-Br46 & 2.172 & 2.169 & 2.182 & 2.169 & 2.171 \\
\hline C17-Br44 & 2.168 & 2.171 & 2.168 & 2.173 & 2.167 \\
\hline M-N24 & - & 1.928 & 1.904 & 1.937 & 1.992 \\
\hline M-N13 & - & 1.929 & 1.908 & 1.935 & 1.998 \\
\hline M-N23 & - & 1.951 & 1.910 & 1.941 & 2.004 \\
\hline M-N14 & - & 1.953 & 1.912 & 1.942 & 2.008 \\
\hline M-C127 & - & 2.382 & 2.371 & 2.362 & 2.352 \\
\hline M-C128 & - & 2.378 & 2.362 & 2.383 & 2.371 \\
\hline Bond angle & & & & & 86.837 .87 \\
\hline C127-M-C128 & - & 177.48 & 176.25 & 178.68 & 178.67 \\
\hline N13-M-N14 & - & 85.85 & 84.33 & 86.47 & 86.87 \\
\hline N14-M-N23 & - & 95.64 & 96.00 & 91.47 & 93.52 \\
\hline N23-M-N24 & - & 86.85 & 86.33 & 84.47 & 86.87 \\
\hline N24-M-N13 & - & 92.66 & 92.70 & 91.30 & 92.12 \\
\hline
\end{tabular}

The calculated energies ( $\mathrm{eV}$ ) of eight important molecular orbitals containing HOMO and LUMO, electronegativity $(\chi)$, chemical potential $(\mu)$ global hardness $(\eta)$ for macrocycle $\mathbf{1}$ and its complexes are listed in Table 4. The HOMO and LUMO orbitals for $\mathbf{1}$ and complex $\mathbf{3}$ are also shown in Figures 3 and $\mathbf{4}$ respectively.

The $\mathrm{E}_{\text {номо }}$ and $\mathrm{E}_{\text {Luмо }}$ and their neighbouring orbitals are all negative, which demonstrate that the prepared complexes are stable. ${ }^{57}$ The energy gap $\left(\mathrm{E}_{\text {LUмо }}-\mathrm{E}_{\text {номо }}\right)$ is an important stability index helps to characterize the kinetic stability and chemical reactivity of the molecule. The energy gap of $\mathbf{1}$ is small which means that charge transfer easily occurs, and therefore influences the biological activity of the molecule..$^{58}$

Mulliken atomic charge calculation has a significant role in the application of quantum chemical calculations to molecular systems. This is because the atomic charges affect some properties of molecular systems including dipole moment, and molecular polarizability. ${ }^{59}$
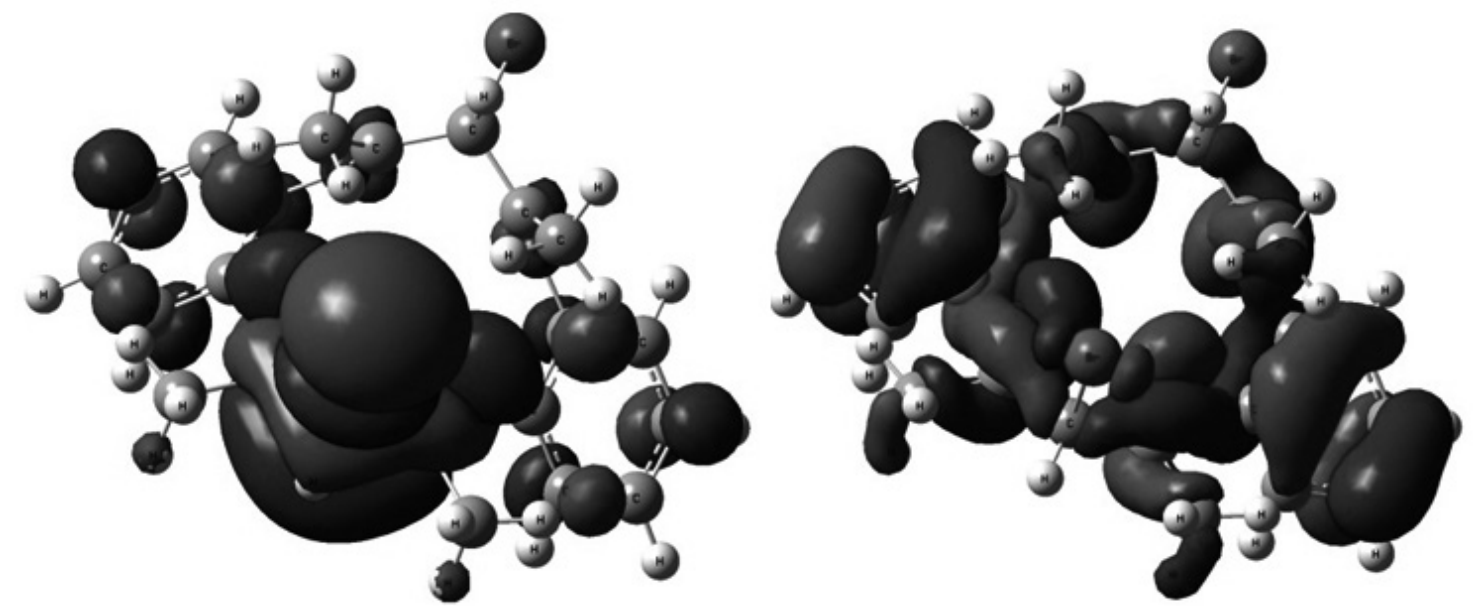

Figure 3 Graphical presentation of calculated frontier orbitals of 1. LUMO orbital (left) and HOMO orbital (right). 

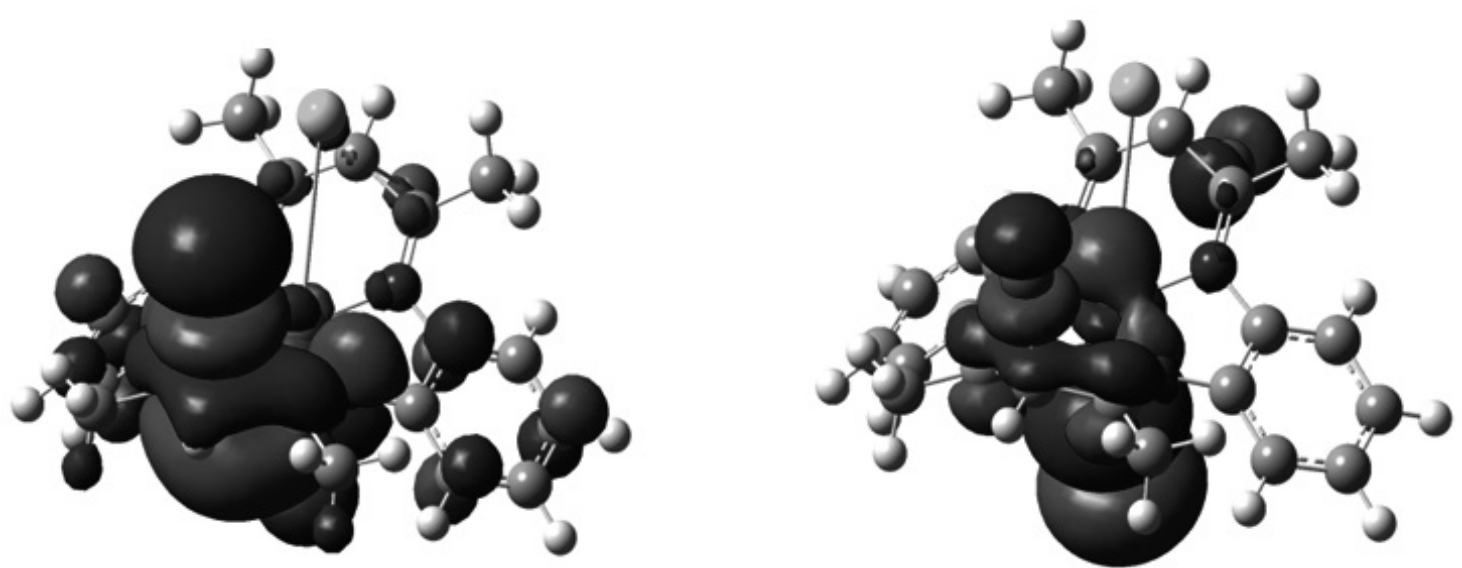

Figure 4 Graphical presentation of LUMO orbital (left) and HOMO orbital for 3 with together their contribution and energies.

Table 4 Calculated energies $(\mathrm{eV})$ of eight important molecular orbitals, chemical potential $(\mu)$, electronegativity $(\chi)$, and global hardness $(\eta)$ for $1(\mathrm{~L})$ and its complexes.

\begin{tabular}{|c|c|c|c|c|c|}
\hline & $\mathrm{L}$ & {$\left[\mathrm{Co}(\mathrm{L}) \mathrm{Cl}_{2}\right]$} & {$\left[\mathrm{Ni}(\mathrm{L}) \mathrm{Cl}_{2}\right]$} & {$\left[\mathrm{Cu}(\mathrm{L}) \mathrm{Cl}_{2}\right]$} & {$\left[\mathrm{Zn}(\mathrm{L}) \mathrm{Cl}_{2}\right]$} \\
\hline LUMO+3 & -0.213 & -1.045 & -1.147 & -1.074 & -0.094 \\
\hline LUMO+2 & -0.325 & -1.920 & -1.820 & -1.718 & -1.417 \\
\hline LUMO+1 & -0.428 & -2.722 & -2.514 & -2.551 & -2.424 \\
\hline LUMO & -0.534 & -3.313 & -3.552 & -3.305 & -3.208 \\
\hline HOMO & -0.758 & -5.448 & -5.258 & -5.355 & -5.782 \\
\hline HOMO-1 & -0.836 & -6.215 & -6.427 & -6.548 & -6.473 \\
\hline HOMO-2 & -0.916 & -7.576 & -7.524 & -7.926 & -8.114 \\
\hline HOMO-3 & -1.117 & -9.340 & -8.975 & -9.250 & -9.127 \\
\hline Gap energy & 0.224 & 0.213 & 1.700 & 2.050 & 2.580 \\
\hline EA & 0.534 & 3.313 & 3.552 & 3.305 & 3.208 \\
\hline IE & 0.758 & 5.448 & 5.258 & 5.355 & 5.782 \\
\hline$\mu$ & -0.646 & -4.381 & -4.405 & -4.330 & -4.495 \\
\hline$\eta$ & 0.112 & 1.068 & 0.853 & 1.025 & 1.287 \\
\hline$\chi$ & 0.646 & 4.381 & 4.405 & 4.330 & 4.495 \\
\hline
\end{tabular}

The color range in the scale of positive and negative charge and graphical representation for Mulliken atomic charges of $\mathbf{1}$ and complex $\mathbf{2}$ are shown in Figures 5 and $\mathbf{6}$ respectively. The selected net charges at the atomic sites of $\mathbf{1}$ and its complexes are given in Table $\mathbf{5}$.

Our findings can be summarized as follows:

i) The charges on two of the hydrogen atoms (H41 and H44) are greater than other hydrogen atoms in the all compounds. This is because they are connected to carbon atoms $(\mathrm{C} 17$ and $\mathrm{C} 18)$ containing electronegative bromine atom

ii) Carbon atoms of benzene rings $(\mathrm{C} 3, \mathrm{C} 4, \mathrm{C} 5, \mathrm{C} 6$ and $\mathrm{C} 8, \mathrm{C} 9, \mathrm{C} 10$, $\mathrm{C} 11)$ have negative charges, while other atoms of benzene rings $(\mathrm{C} 1, \mathrm{C} 2$ and $\mathrm{C} 7, \mathrm{C} 12)$ have positive charges. This later is because they are connected to nitrogen atoms of imine groups (N23, N24 and N13, N14).

iii) The charge of the $\mathrm{Co}^{2+}$ ion in the Free State is +2.0 . It is seen that the positive charge of the metal ion decreases to +0.091 in 2 , which indicates that transfer of electrons from 1 to the metal ion has occurred and the coordination bonds have formed. Our calculations show that a total of $-1.293 \mathrm{e}$ is transferred to $\mathrm{Zn}$ (II) during the coordination process, and the net charge on the $\mathrm{Zn}$ (II) reduces to +0.707 e. Similar behaviour in charge transfer is noted in case of complexes 3 and $\mathbf{4}$. The charge on central metal ion after coordination reduces to +0.308 and +0.318 respectively.

iv) The charge of the chloride ion in the Free State is -1.0. It is seen that the negative charge of the chloride ion decreases to $-0.238 \mathrm{e}$ in 2 , which indicates that the transfer of electrons from chloride ion to the metal ion has occurred, and the coordination bonds have formed. Our calculations show that a charge equal $-0.477 \mathrm{e}$ from chloride ion is transferred to $\mathrm{Zn}$ (II) during the coordination process, and the net charge on chloride ion reduces to $-0.523 \mathrm{e}$. Similar behaviour of charge transfer is noted in the case of complexes 3 and $\mathbf{4}$. The charge on chloride ion after coordination reduces to $-0.468 \mathrm{e}$ and $-0.431 \mathrm{e}$ respectively.

v) Thus it can be concluded from the distribution of electric charges on the atoms of the complexes that much electron transfer occurs from the macrocycle to the metal ions, and therefore a strong interaction occurs between the macrocycle 1 with metal(II) ions. 
Table 5 Selected net charges at the atomic sites of macrocycle 1 (L) and its complexes.

\begin{tabular}{|c|c|c|c|c|c|}
\hline atoms & $\mathrm{L}$ & {$\left[\mathrm{Co}(\mathrm{L}) \mathrm{Cl}_{2}\right]$} & {$\left[\mathrm{Ni}(\mathrm{L}) \mathrm{Cl}_{2}\right]$} & {$\left[\mathrm{Cu}(\mathrm{L}) \mathrm{Cl}_{2}\right]$} & {$\left[\mathrm{Zn}(\mathrm{L}) \mathrm{Cl}_{2}\right]$} \\
\hline $\mathrm{C} 1$ & 0.080 & 0.219 & 0.238 & 0.226 & 0.172 \\
\hline $\mathrm{C} 2$ & 0.116 & 0.276 & 0.248 & 0.260 & 0.235 \\
\hline $\mathrm{C} 7$ & 0.116 & 0.276 & 0.248 & 0.260 & 0.235 \\
\hline $\mathrm{C} 12$ & 0.080 & 0.219 & 0.238 & 0.226 & 0.172 \\
\hline $\mathrm{C} 15$ & 0.231 & 0.406 & 0.420 & 0.400 & 0.381 \\
\hline $\mathrm{C} 16$ & 0.199 & 0.424 & 0.411 & 0.391 & 0.348 \\
\hline $\mathrm{C} 17$ & -0.613 & -0.646 & -0.680 & -0.651 & -0.632 \\
\hline $\mathrm{C} 18$ & -0.617 & -0.754 & -0.754 & -0.761 & -0.745 \\
\hline $\mathrm{C} 19$ & -0.741 & -0.758 & -0.752 & -0.747 & -0.728 \\
\hline $\mathrm{C} 20$ & -0.756 & -0.765 & -0.760 & -0.750 & -0.743 \\
\hline $\mathrm{C} 21$ & 0.199 & 0.424 & 0.411 & 0.391 & 0.348 \\
\hline $\mathrm{C} 22$ & 0.231 & 0.406 & 0.420 & 0.400 & 0.381 \\
\hline $\mathrm{C} 25$ & -0.756 & -0.765 & -0.760 & -0.750 & -0.743 \\
\hline $\mathrm{C} 26$ & -0.741 & -0.758 & -0.752 & -0.747 & -0.728 \\
\hline N13 & 0.025 & -0.265 & -0.263 & -0.270 & -0.328 \\
\hline N14 & 0.025 & -0.171 & -0.217 & -0.207 & -0.236 \\
\hline N23 & 0.025 & -0.171 & -0.217 & -0.207 & -0.236 \\
\hline N24 & 0.025 & -0.265 & -0.263 & -0.270 & -0.328 \\
\hline M & & 0.091 & 0.308 & 0.318 & 0.707 \\
\hline $\mathrm{C} 128$ & & -0.238 & -0.468 & -0.431 & -0.523 \\
\hline $\mathrm{Cl} 29$ & & -0.243 & -0.156 & -0.215 & -0.434 \\
\hline
\end{tabular}

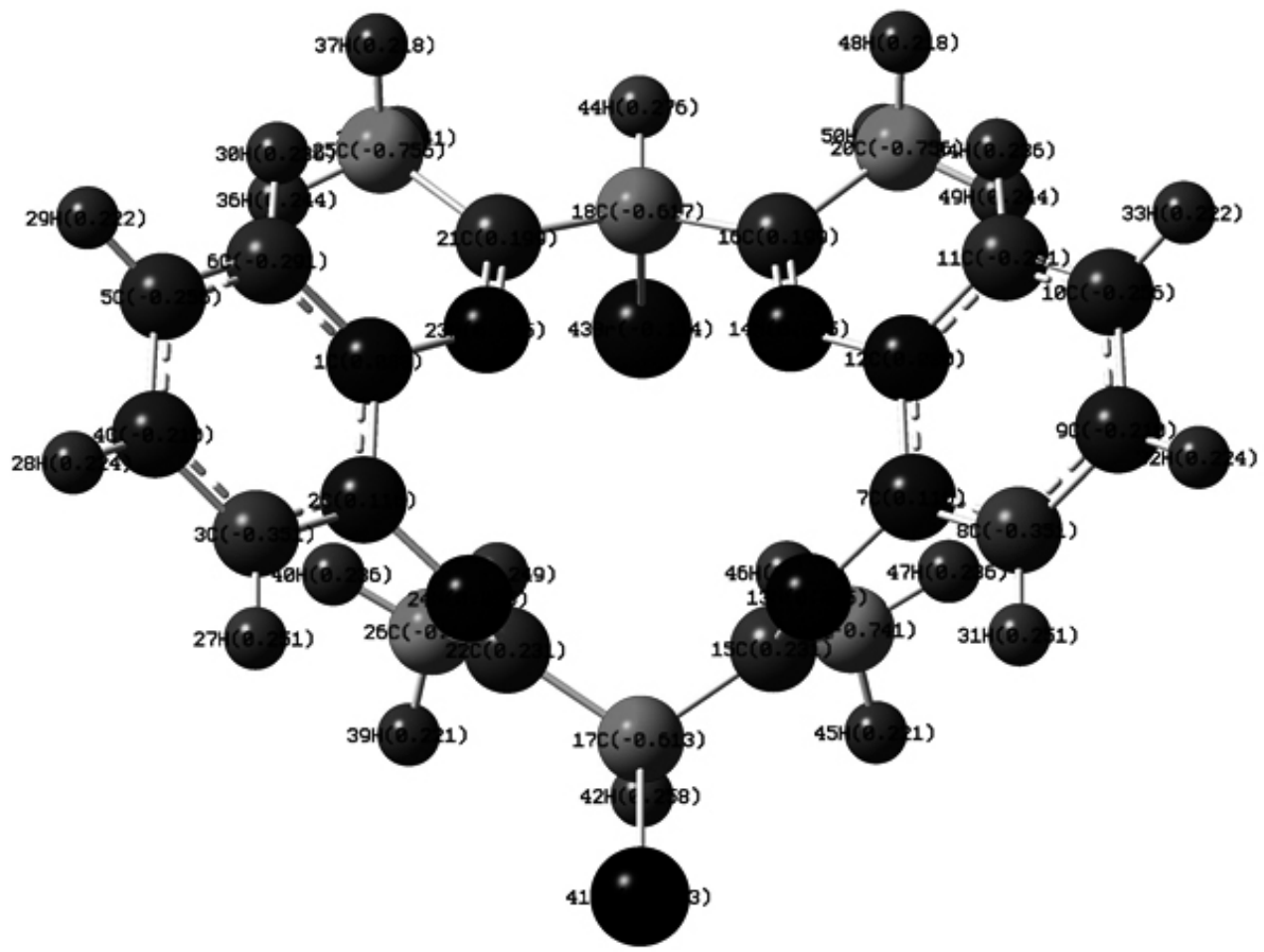

Figure 5 Graphical representation for Mulliken atomic charges of the macrocycle 1. 


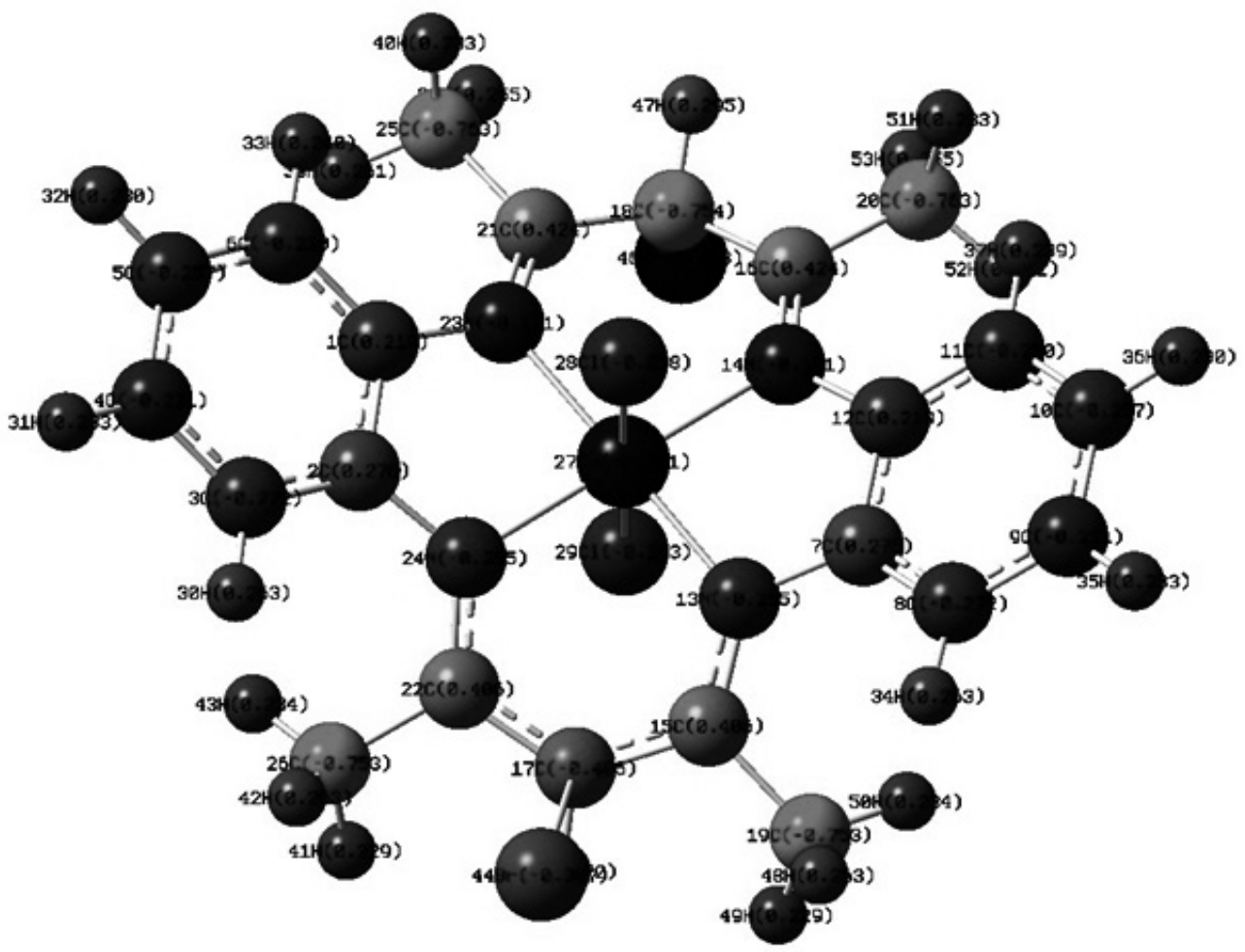

Figure 6 Graphical representation for Mulliken atomic charges of the complex 2.

\section{CONCLUSIONS}

A new macrocycle Schiff base $\mathbf{1}$ is prepared by the reaction between benzene-1,2-diamine and 3-bromo-pentane-2,4-dione, and a series of its complexes with $\mathrm{Co}(\mathrm{II}), \mathrm{Ni}(\mathrm{II}), \mathrm{Cu}(\mathrm{II})$ and $\mathrm{Zn}$ (II) have been synthesized. The complexes have the general formula $\left[\mathrm{M}(\mathrm{L}) \mathrm{Cl}_{2}\right]$ where $\mathrm{M}=\mathrm{Co}$ (II) 2, Ni(II) 3, $\mathrm{Cu}(\mathrm{II}) \mathbf{4}$, and $\mathrm{Zn}$ (II) 5 respectively? .

The spectroscopic data such as NMR and IR also molar conductivity values and magnetic moments of $\mathbf{1}$ and its complexes with above mentioned metals, suggest that $\mathbf{1}$ is connected to metal(II) ions through four nitrogen atoms of imine groups. The magnetic moments and electronic spectral data of these complexes are in good agreement to the octahedral coordination of M(II) ions. Thermal gravimetric analyses displayed that these complexes can be stable up to $231{ }^{\circ} \mathrm{C}$.

The macrocycle $\mathbf{1}$ does not show any antimicrobial activity. The complexes 2 and 3 display antibacterial activities against Gram-positive bacteria ( $B$. subtilis and $S$. aurous), while complex $\mathbf{5}$ shows antibacterial activity against Gram-negative bacteria (E. coli and $P$. aeruginosa), and antifungal activity against fungi ( $S$. cerevisiae and $C$. albicans). The complex 4 demonstrates good activity against Gram-positive and Gram-negative bacteria and fungi.

The optimized structures of $\mathbf{1}$ and its complexes were computed by theoretical DFT method, and all the complexes have a distorted octahedral geometry. The HOMO and LUMO energies were also determined. It has been found that small gap energy in $\mathbf{1}$ causes softness and subsequently formed stable complexes with metal(II) ions. The charges on the atoms of compounds have also been calculated, and it has been found that much electron transfer occurs from 1 to the central atoms in the complexes. This behaviour confirms a strong interaction of macrocycle $\mathbf{1}$ with metal(II) ions.

\section{ACKNOWLEDGEMENTS}

The authors would like to thank the Research Council of Shahrood University of Technology for the financial support of this work. Authors also thank Dr. N. Farrokhi from Biology Department, Shahrood University of Technology for microbiology measurements.

\section{REFERENCES}

1. V. Mishra, S. N. Pandeya, S. Anathan, Acta Pharm. Turc. 2000, 42, 139148

2. A. Nishinaga, H. Tomita, K. Nishizawa, T. Matsuura, S. Ooi, K. Hirotsu, J. Chem. Soc., Dalton Trans. 1981, 1504-1514.

3. B. J. Motekaitis, A. E. Martell, D. A. Nelson, Inorg. Chem. 1984, 23, 275283.

4. M. Wang, L. F. Wang, Y. Z. Li, Q. X. Li, Z. D. Xu, D. Q. Qu, Transition Met. Chem. 2001, 26, 307-310.

5. S. Park, V. K. Mathur, R. P. Planalp, Polyhedron 1998, 17, 325-330.

6. X. Ran, L. Wang, Y. Lin, J. Hao, D. Cao, Appl. Organomet. Chem. 2010, 24, 741-747.

7. N. Aggarwal, R. Kumar, P. Dureja, D. S. Rawat, J. Agric. Food. Chem. 2009, 57, 8520-8525.

8. Y. W. Ren, H. Guo, C. Wang, J. J. Liu, H. Jiao, J. Li, F. X. Zhang, Transition Met. Chem. 2006, 31, 611-615.

9. M. Salavati-Niasari, M. Rezai-Adaryni, S. Heydarzadeh, Transition Met. Chem. 2005, 30, 445-450.

10. E. C. Constable, Coordination chemistry of macrocyclic compounds, University Press, Oxford, 1999.

11. D. P. Singh, R. Kumar, V. Malik, P. Tyagi, Transition Met. Chem. 2007, 32, 1051-1055.

12. D. P. Singh, R. Kumar, V. Malik, P. Tyagi, J. Enz. Inhib. Med. Chem. 2007, 22, 177-182.

13. R. V. Singh, A. Chaudhary, J. Inorg. Biochem. 2004, 98, 1712-1721.

14. A. Mobinikhaledi, M. Jabbarpour, A. Hamta, J. Chil. Chem. Soc. 2011, 56, 812-814.

15. S. M. Abdallah, M. A. Zayed, G. G. Mohamed, Arab. J. Chem. 2010, 3, 103-113.

16. Q.-B. Li, L.-W. Xue, W.-C. Yang, G.-Q. Zhao, J. Chil. Chem. Soc. 2013, 58, $1880-1883$.

17. D. P. Singh, R. Kumar, M. Kamboj, K. Jain, Acta Chim. Slov. 2009, 56, 780-785.

18. S. Han, Y. Wang, J. Chil. Chem. Soc. 2014, 59, 2753-2755.

19. G. G. Mohamed, M. A. Badawy, M. M. Omar, M. M. Nassar, A. B. Kamel, 
Spectrochim. Acta A 2010, 77, 773-781.

20. W. Li, Y. Ding, X.-S. Cheng, Z. You, J. Chil. Chem. Soc. 2015, 60, $3034-$ 3037.

21. M. Shakir, N. Shahid, N. Sami, M. Azam, A. U. Khan, Spectrochim. Acta A 2011, 82, 31-33.

22. A. Reiss, A. Samide, G. Ciobanu, I. Dabuleanu, J. Chil. Chem, Sic. 2015 , 60, 3074-3079.

23. R. N. Prasad, S. Gupta, J. Serb. Chem. Soc. 2002, 67, 523-530.

24. M. B. Ferrari, C. Pelizzi, G. Pelosi, M. C. Rodríguez-Argüelles, Polyhedron 2002, 21, 2593-2599.

25. D. P. Singh, R. Kumar, P. Tyagi, Transition Met. Chem. 2006, 31, 970-973.

26. A. Chaudhary, R. Swaroop, R. Singh, Bol. Soc. Chile Quím. 2002, 47, 203-211.

27. A. D. Becke, J. Chem. Phys. 1993, 98, 5648-5652.

28. M. J. Frisch, G. W. Trucks, H. B. Schlegel, G. E. Scuseria, M. A. Robb, J. R. Cheeseman, J. A. Montgomery, J. T. Vreven, K. N. Kudin, J. C. Burant, J. M. Millam, S. S. Iyenga, J. Chen, M. W. Wong, C. Gonzalez, J. A. Pople, Gaussian 03, Revision A.1. Pittsburgh, PA, Gaussian Inc. 2007.

29. R. J. Parr, R. G. Pearson, J. Am. Chem. Soc. 1983, 105, 7512-7516.

30. S. Khan, S. A. A. Nami, K. S. Siddiqi, Spectrochim. Acta A, 2007, 68 269-274.

31. B. H. M. Mruthyunjayaswamy, B. I. Omkar, Y. Jadegoud, J. Brazil. Chem. Soc. 2005, 16, 783-789.

32. W. G. Geary, Coord. Chem. Rev. 1971, 7, 81-122.

33. K. Nakamoto, Infrared and Raman spectroscopy of inorganic and coordination compounds, Wiley-Interscience, New York, 1978.

34. M. Salavati-Niasari, F. Davar, Inorg. Chem. Commun. 2006, 9, 175-179.

35. P. S. Kalsi, Spectroscopy of organic compounds, New Age International (P) Ltd., New Delhi, 1999.

36. J. R. Dyer, Application of absorptions spectroscopy of organic compounds, Prentice Hall, New Delhi, 1991.

37. S. Sarkar, K. Dey, Spectrochim. Acta A 2010, 77, 740-748.

38. J. Huang, S. A. Li, D. F. Li, D. X. Yang, W. Y. Sun, W. X. Tang, Bioorg. Med. Chem. 2004, 12, 529-535.

39. P. E. Aranha, M. P. Doe Santos, S. Romera, E. R. Dockal, Polyhedron 2007, 26, 1373-1382.

40. I. Demir, M. Bayrakci, K. Mutlu, A. I. Pekacar, Acta Chim. Slov. 2008, 55,
$120-124$.

41. R. C. Maurya, P. Patel, S. Rajput, Synth. React. Inorg. Met.-Org. Chem. 2003, 33, 817-836.

42. S. Arunachalam, N. P. Priya, C. Jayabalakrishnan, V. Chinnusamy, Spectrochim. Acta A 2009, 74, 591-596.

43. M. S. Refat, S. A. El-Korashy, D. N. Kumar, A. S. Ahmed, Spectrochim. Acta A 2008, 70, 898-906.

44. F. A. Cotton, G. Wilkinson, C. A. Murillo, M. Bochmann, Advanced inorganic chemistry, 6th ed., Wiley-Interscience, New York, 1999.

45. D. Sutton, Electronic spectra of transition metal complexes, McGraw-Hill, London, 1968.

46. A. B. P. Lever, Inorganic electronic spectroscopy, 2nd ed., Elsevier, Amsterdam, 1984.

47. S. Chattopadhyay, M. G. B. Drew, A. Ghosh, Polyhedron 2007, 26, 3513 3522 .

48. S. Banerjee, J. Gangopadhyay, C. Z. Lu, J. T. Chen, A. Ghosh, Eur. J. Inorg. Chem. 2004, 2533-2541.

49. G. L. Miessler, D. A. Tarr, Inorganic chemistry, 3rd ed., Pearson prentice Hall, London, 1994.

50. B. E. Douglas, D. H. McDaniel, J. J. Alexander, Concepts and models of inorganic chemistry, 3rd ed., John Wiley and Sons Inc., New York, 1994.

51. M. Salavati-Niasari, F. Davar, Polyhedron 2006, 25, 2127-2134.

52. S. Srivastava, A. Kalam, Synth. React. Inorg. Met.-Org. Chem. 2004, 34, $1529-1541$

53. M. M. Omar, G. G. Mohamed, A. A. Ibrahim, Spectrochim. Acta A 2009, 73, 358-369.

54. F. Rafat, K. S. Siddiqi, J. Korean Chem. Soc. 2011, 55, 912-918.

55. L. Mallesha, K. N. Mohana, J. Chem. Pharm. Res. 2007, 2, 75-82.

56. H. Keypour, M. Shayesteh, M. Rezaeivala, F. Chalabian, L. Valencia, Spectrochim. Acta A 2013, 101, 59-66.

57. O. A. El-Gammal, M. M. Bekheit, S. S. El-Brashy, Spectrochim. Acta A 2015, 137, 207-219.

58. S. Mondal, S. Naskar, A. K. Dey, E. Sinn, C. Eribal, S. R. Herron, S. K. Chattopadhyay, Inorg. Chim. Acta 2013, 398, 98-105.

59. M. Gaber, H. El-Ghamry, F. Atlam, S. Fathalla, Spectrochim. Acta A 2015, 137, 919-929. 